\begin{tabular}{|l|l|l|l|l|l|} 
J. Tek. Ling & Vol.11 & No.3 & Hal. 389 - 399 & Jakarta, September 2010 & ISSN 1441-318X \\
\hline
\end{tabular}

\title{
PRODUKSI GAS METANA DARI PENGOLAHAN SAMPAH PERKOTAAN DENGAN SISTEM SEL
}

\author{
Arie Herlambang, Henky Sutanto dan Kusno Wibowo \\ Peneliti di Pusat Teknologi Lingkungan \\ Bada Pengkajian dan Penerapan Teknologi
}

\begin{abstract}
Abstrac
Waste to energy now become one of the technology solution that is in many developed countries, in an effort to reduce greenhouse gas emissions from waste. Urban organic waste is a potential source of greenhouse gases. Methane gas is an energy source that can be used as fuel. It is difficult to find land for Landfill alocation in the major cities and often becomes a difficult social problem. Structured Landfill Cell is used to treat the waste at the landfill, with the aim to use land more scalable, easier waste management and control, better sanitation, better water control leachate and gas produced can be managed optimally and compost can be utilized with the production and quality control. This new system was first used in Indonesia by PT Navigats Organics Energy Indonesia in landfill Suwung, Denpasar, Bali. There are 5 cells already built in Suwung and two of cells have been filled with garbage. Each cell contains $12,000 \mathrm{~m}^{3}$ soliswaste. Observations carried out on gas productivity of two cells that have been filled, with a dry treatment on cell 1 (dry cell) and a wet treatment in cell 2 (wet cell). The observed gas is $\mathrm{CH}_{4}, \mathrm{CO}_{2}$, and $\mathrm{O}_{2}$ as the main parameters, with the addition parameters are $\mathrm{CO}$ and $\mathrm{H}_{2} \mathrm{~S}$. The instrument used is the GA 2000 Plus. Observations of two cells made for 4 months, with the content of $\mathrm{CH}_{4}$ around 40 to $50 \%$ in the first month and gradually decreased to reach 18 to $25 \%$ in the fourth month. Carbondioxyde going up and down following condition of $\mathrm{CH}_{4}$ and its value ranges between 16 and $28 \%$. Oxygen consentration around 2 to $14 \%$. For keeping engine performance the consentration of methane should more than $28 \%$ and $\mathrm{O}_{2}$ content lower than $6 \%$. Cell with watering will temporarily reduce $\mathrm{CH}_{4}$ and $\mathrm{CO}_{2}$ and $\mathrm{O}_{2}$ increase, but it is slowly rising again. Carbonmonoside values tend to increase with age garbage (10 sd 350 ppm), whereas irregular $\mathrm{H}_{2} \mathrm{~S}$ values ranging 0 up to 24 ppm, allegedly associated with the low protein content in the trash. Sewage treatment system is proven to increase $\mathrm{CH}_{4}$ gas, yet still needed modifications of structure and the gas collector pipe system so that productivity can be improved.
\end{abstract}

Key Words : Solidwaste, Metana, Cell System

\section{PENDAHULUAN}

\subsection{Latar Belakang}

Sampah yang berasal dari aktivitas penduduk di perkotaan sangat besar jumlahnya dan diduga berpotensi sebagai sumber gas metana. Gas metana merupakan salah satu Gas Rumah Kaca (GRK) yang dapat menyebabkan efek rumah kaca, sebagai penyebab terjadinya pemanasan global (Global Warming). Saat ini terdapat kurang lebih 450 TPA di kota besar dengan sistem open dumping dan baru sebagian kecil yang dikembangkan menjadi controled landfil. Potensi sampah yang dapat dihasilkan dari 
45 kota besar di Indonesia mencapai 4 juta ton/tahun. Potensi gas metana yang bisa dihasilkan mencapai 11.390 ton $\mathrm{CH}_{4} /$ tahun atau setara dengan 239.199 ton $\mathrm{CO}_{2}$ / tahun, jumlah ini merupakan $64 \%$ dari total emisi sampah berasal dari 10 kota besar, antara lain : Jakarta, Surabaya, Bandung,Medan, Semarang, Palembang, Makasar, Bekasi, Depok, dan Tanggerang (Gambar 1 dan 2). ${ }^{5}$ )

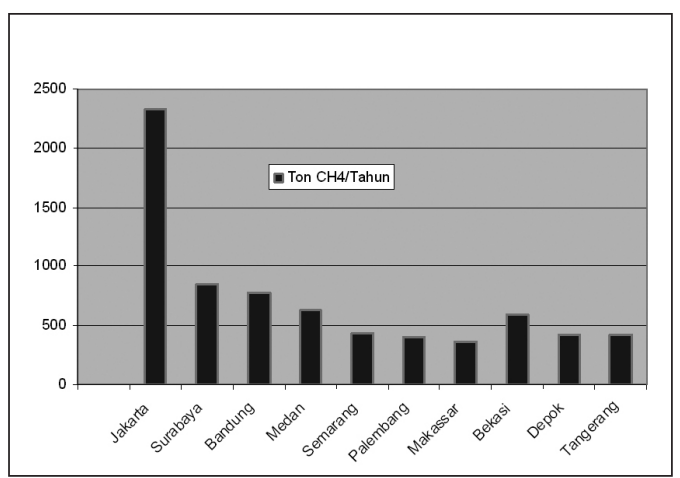

Gambar 1. Potensi Gas Metana dari 10 kota besar di Indonesia. ${ }^{5}$

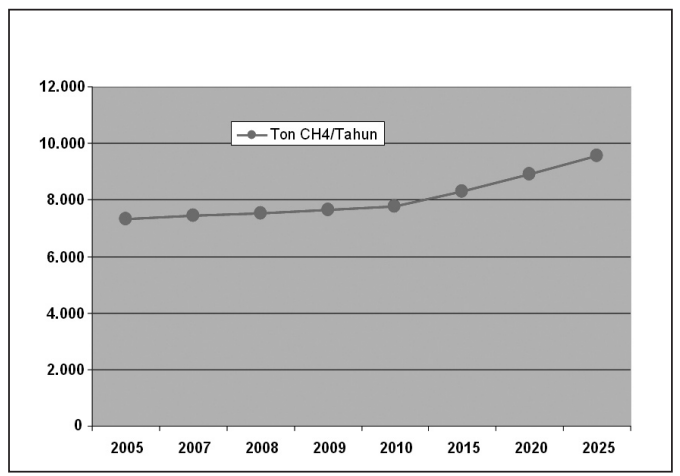

Gambar 2. Proyeksi Potensi Gas Metana total dari 10 kota besar di Indonesia.5)

Gambaran besarnya potensi GRK dari sampah ini, menuntut perubahan didalam pengelolaan sampah di Indonesia, oleh karena itu dalam Undang-Undang Nomor 18 Tahun 2008 tentang Pengelolaan Persampahan, menyatakan bahwa pengelolaan sampah diselenggarakan berdasarkan azas tanggung jawab, berkelanjutan, manfaat, keadilan, kesadaran, kebersamaan, keselamatan, keamanan, dan nilai ekonomi, dengan tujuan meningkatkan kesehatan masyarakat dan kualitas lingkungan serta menjadikan sampah sebagai sumber daya. Kondisi ini akan lebih optimal bila ditunjang dengan pemilahan sampah di sumbernya dan di Tempat Pengelolaan Sampah Terpadu (TPST).

Saat ini sudah beberapa kota membangun atau memodifikasi TPA-nya dengan sistem Sanitary Landfil (SL). Gas yang dihasilkan dari SL dapat digunakan untuk pembangkit listrik, bahan bakar kendaraan, dan dapat dikonversi nilainya dalam perdagangan karbon internasional.

\subsection{Perumusan Masalah}

Pengolahan sampah kota, dimulai dari pengumpulan dan pemilahan sampah di rumah tangga, perkantoran, pertokoan, dan perhotelan dengan menggunakan Sistem 3R (Reduce, Reuse, Recycle), yang kemudian oleh pengumpul (dengan menggunakan gerobak sampah) dikumpulkan di Tempat Pembuangan Sampah Sementara (TPS). Sampah dari TPS kemudian diangkut dengan sistem transportasi sampah dengan menggunakan truk pengangkut sampah khusus, untuk dibuang ke Tempat Pembuangan Akhir (TPA). Pengolahan sampah di TPA, pada umumnya saat ini baru ditumpuk saja, sehingga menggunung dan sering menimbulkan bencana akibat runtuhnya (sliding) tumpukan sampah (open dumping).

Sistem Open Dumping merupakan sumber bagi emisi gas Metana ke atmosfir dan menimbulkan efek gas rumah kaca serta memberi kontribusi terhadap global warming. Sebagai pengembang-an lebih lanjut, kemudian digunakan Sistem Sanitary Landfill $(\mathrm{SL})$, dengan tujuan agar pengelolaan sampah di TPA lebih higienis, bersih dan air lindinya tertata dan diolah dengan baik.

Gas metana yang dihasilkan dikumpulkan dengan dihisap dengan menggunakan pompa hisap melalui sistem perpipaan gas yang ditanam di dalam sampah, kemudian dikumpulkan dalam gas treatment. Gas metana tersebut dapat 
digunakan untuk pembangkit listrik atau bahan bakar kendaraan bermotor setelah diubah menjadi CNG. Di beberapa negara maju, listrik yang dihasilkan dari proses degradasi pembusukan sampah secara anaerobik ini, dihargai sampai dua kali harga listrik PLN asal energi konvensional.

Sampah yang sudah tidak menghasilkan gas, kemudian dapat ditambang dan diolah untuk dijadikan pupuk kompos atau dapat digunakan sebagai bahan bakar dalam system insinerator dan pirolisis yang panasnya dimanfaatkan untuk menggerakkan turbin listrik, sedangkan sampah plastiknya digunakan kembali (recyle) untuk keperluan bahan baku iondustri. Sistem SL ini masih dirasa cukup mahal konstruksinya dan dengan bertambah-nya jumlah sampah, luasan sistem SL juga bertambah, di beberapa kota besar, lahan menjadi kendala bagi penempatan sarana SL.

Di Masyarakat Ekonomi Eropa, dimana pengurangan jumlah emisi gas metana menjadi prasarat bagi TPA SL yang baik, maka telah dikembangkan Teknologi Mechanical Biological Treatment (MBT). Sampah yang akan diolah dalam Sistem SL telah berkurang kadar organiknya (tidak lebih dari $5 \%$ ), sehingga produksi gas metana dari pembusukan anaerobiknya juga berkurang. Sistem ini masih sulit diterapkan di Indonesia, selain investasinya tinggi, kandungan organik sampah di Indonesia rata-rata masih sekitar $60 \%{ }^{6}{ }^{6}$

Sulitnya mencari lahan untuk TPA, menimbulkan ide munculnya sistem Reusable Sanitary Landfill (RSL-Wet Cell), yang merupakan pengem-bangan dari sistem Sanitary Landfill (SL-Dry Cell), dengan menggunakan sistem basah (resirkulasi lindi) dan adanya kompos mining secara berkala, sehingga lahan dapat dipakai kembali untuk sampah yang baru. RSL ini masih dalam tahap penelitian dan masih dalam proses pengkajian untuk menentukan standard desain teknis dan operasionalnya di TPA Bangli.

Pengelolaan sampah sistem sel (Cell System), merupakan intermediate treatment, karena sistem ini masih dilengkapi juga dengan sistem pengolahan sampah kompos organik, pengolahan plastik dan pengolahan logam dan pemisahan Bahan Beracun dan Berbahaya. Sel ini terbuat dari konstruksi beton bertulang, dengan ukuran yang disesuaikan dengan kapasitas produksi sampah harian kota yang dilayani.

Sebagai contoh di Pengolahan Sampah Sarbagita (Denpasar, Badung, Gianyar, Tabanan), di TPA Suwung, Denpasar, Bali, kapasitas setiap sel $12.000 \mathrm{~m}^{3}$, saat ini telah terbangun 5 sel (rencana akan dibangun 11 sel). Dari 5 sel yang terbangun baru dua sel yang terisi oleh sampah campuran. Dengan Pengelolaan Sampah Sistem Sel ini sampah lebih terukur jumlah dan waktu pengisiannya, memudahkan dalam pemanenan gas dan pengendalian air lindinya, pemanenan kompos bisa diprediksi waktunya. Kedua sel ini (wet cell \& dry cell). Dapat dimanfaatkan sebagai simulator TPA SL dan TPA RSL.

Permasalahan yang muncul didalam pelaksanaan adalah jumlah gas yang dihasilkan belum optimal, sehingga listrik yang dihasilkan juga belum optimal.

Belum optimalnya produksi gas dari system sel dapat diduga akibat : 1). Kandungan air dalam sampah yang rendah, sehingga mem-pengaruhi proses pembusukan (biologi), 2). Penutupan sel tidak sempurna (terjadi kebocoran), sehingga gas metana banyak keluar dan sistem kemasukan oksigen dari udara. 3). Penghisapan gas dengan pompa vakum terlampau cepat (kuat), melebihi laju produksi gas metana di dalam sistem sel, 4). Sampah yang dimasukkan dalam sistem sel belum tersortasi dengan baik, sehingga masih banyak dijumpai bahan anorganiknya. 5). Perubahan iklim dari musim hujan ke musim kemarau mempengaruhi pola curah hujan dan temperature udara.

\subsection{Maksud dan Tujuan}

Penelitian ini bermaksud melakukan kajian pengolahan sampah perkotaan 
dengan sistem sel, dengan tujuan :

1. Melakukan pengukuran gas di TPA Sistem Sel basah dan kering di Suwung, Denpasar, Bali. Untuk mendapatkan laju produksi gas $\left(\mathrm{CH}_{4}\right.$, $\mathrm{CO}_{2}, \mathrm{O}_{2}, \mathrm{H}_{2} \mathrm{~S}$ dan $\mathrm{CO}$ ) dalam fungsi waktu.

2. Membuat evaluasi Kinerja dan optimalisasi desain pengolahan sampah sistem sel untuk aplikasi pengolahan sampah perkotaan skala sedang (300 $\mathrm{s} / \mathrm{d} 500 \mathrm{~m}^{3}$ sampah/hari).

3. Masukkan bagi usulan kebijakan pengelola sampah kota skala sedang kepada lembaga atau departemen terkait untuk perbaikan penerapan implemen-tasi di lapangannya.

4. Mengetahui perbedaan sistem basah dan sistem kering ditinjau dari produksi gasnya.

\subsection{Metodologi}

Berdasarkan permasalahan yang ada, maka dikembangkan metodologi penelitian untuk mencari penyebab penurunan produktiftas gas.

1. Jumlah Sel sampah yang digunakan percobaan terdiri dari dua buah sel. Sel berbentuk segi empat dengan ukuran lebar $15 \mathrm{~m}$ x panjang $24 \mathrm{~m}$ dan tinggi 10 meter (volume sampah $12.000 \mathrm{~m}^{3}$ ).

2. Setiap sel dilengkapi dengan sumur penyalur gas, sistem penyiraman untuk menjaga kelembaban dan sistem penyaluran air lindi.

3. Masing-masing sel diisi dengan sampah campuran sampai penuh, kemudian ditutup dengan terpal penutup, agar kedap udara, untuk menangkap produksi gas yang muncul (khusus sel basah).

4. Sel pertama (Sel 1) diperlakukan sebagai sel kering dengan kelembaban $50-55 \%$ dan Sel kedua (Sel 2) diperlakukan sebagai sel basah dengan kelembaban $60-65 \%$.

5. Parameter yang diukur adalah gas $\mathrm{CH}^{4}, \mathrm{CO}_{2}, \mathrm{O}_{2}$, dan $\mathrm{CO}$ dan $\mathrm{H}_{2} \mathrm{~S}$, serta laju alir gas, tekanan, temperatur udara.

6. Pengukuran dilakukan pada setiap sel di lokasi sampel setiap hari, pagi dan sore hari.

\subsection{Lokasi Penelitian}

Tempat Pembuangan Akhir (TPA) Sampah Sistem Sel, merupakan tempat pembuangan sampah intermediate yang ditujukan untuk menampung sampah dengan skala yang terukur dengan memperhitungkan proses pembentukan gas dan kematangan proses komposting, sehingga dengan memperhitungkan potensi sampah di wilayah tertentu, kita bisa menentukan ukuran sel dan jumlahnya serta energi yang dihasilkan. Lokasi Penelitian dilakukan di TPA Suwung, Denpasar, Bali di lokasi PT. NOEI.

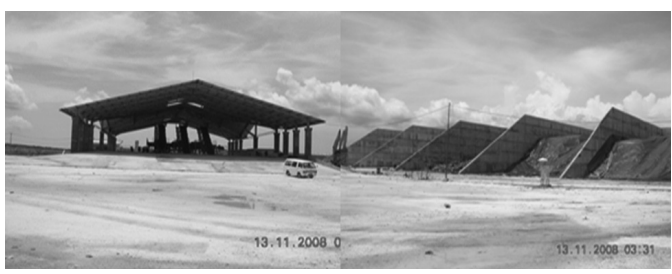

Gambar 3 : Lokasi Tpa Sistem Sel Di Suwung, Denpasar, Bali.

\subsection{Peralatan Yang Digunakan}

Untuk melakukan pengamatan gas TPA diperlukan beberapa alat ukur dan alat bantu pengukuran, yakni :

1. Landfill Gas Analyser (GA2000Plus) Alat ini digunakan untuk mengamati parameter gas yang dihasilkan oleh sebuah TPA, yakni :

- Metan $\left(\mathrm{CH}_{4}\right)$ dalam satuan \%

- Karbon dioksida $\left(\mathrm{CO}_{2}\right)$ dalam satuan \%

- Oksigen $\left(\mathrm{O}_{2}\right)$ dalam satuan \%

- Hidrogen sulfida $\left(\mathrm{H}_{2} \mathrm{~S}\right)$ dalam satuan ppm 
- Karbon monoksida (CO) dalam satuan ppm

2. Analog Landfill Gas Measurement Instrument (ALGMI).

Alat ini terdiri dari beberapa alat ukur dengan spesifikasi sebagai berikut :

- Ukuran pipa 2"

- Pengukur suhu $0-100^{\circ} \mathrm{C}$

- Pengukur tekanan 0 - 150 mbar

- Pengukur debit gas $<500 \mathrm{cc} / \mathrm{mnt}$ Double outlet kran gas 1/4"

Pemakaian alat ini digabung dengan GA 2000 Plus, untuk melihat tekanan gas, debit penyedotan gas, dan temperature.

3. Gas Flow Meter

Gas Flow Meter digunakan untuk mengukur aliran gas aktif yang keluar dari sumur tanpa dilakukan proses penghisapan oleh pompa vakum. Alat ini menggunakan tenaga baterai, dipasang pada pipa ukuran 2 ", kecepatan alirannya dinyatakan dalam satuan meter per menit.

\subsection{Pelaksanaan Penelitian}

Pelaksanaan penelitian dilaksanakan selama bulan juli sd November 2009. Penelitian dilaksanakan bekerjasama dengan Dinas PU Propinsi Bali, BPKS Sarbagita, dan PT NOEI.

\section{SISTEM SEL SAMPAH SUWUNG}

\subsection{Komposisi Sampah}

Sampah yang dipakai untuk pengisian sel-sel sampah percobaan diambil dari sampah kota Denpasar, Badung, Gianyar dan Tabanan (Sarbagita). Proses pengisian dilakukan selama 36 hari. Komposisi sampah terdiri dari Sampah Organik 65-67\%, Anorganik 33-35\%, Berat Jenis Sampah berkisar 0,16-0,26.

Jika ditinjau dari komposisinya, maka untuk optimalisasi produksi gas akan lebih baik, sampah yang akan dimasukkan kedalam

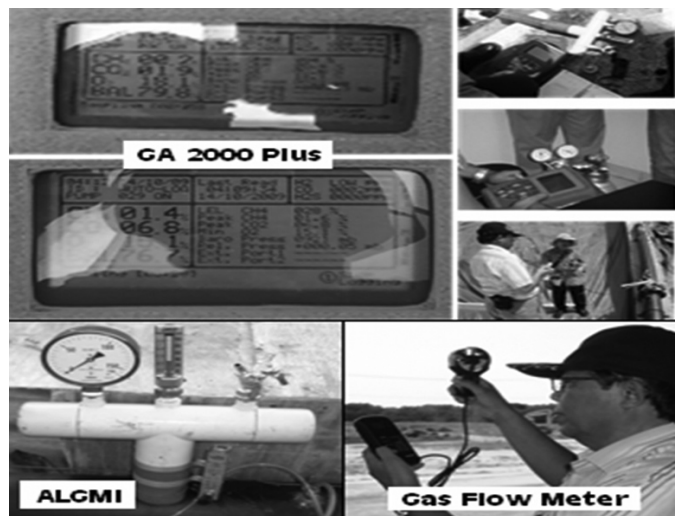

Gambar 4 : Pengoperasian GA2000Plus, ALGMI dan Gas Flow Meter.

sel sampah dilakukan pemilahan terlebih dahulu, agar komposisi bahan organiknya bisa lebih ditingkatkan sampai dengan 80 $90 \%$, dengan demikian dapat diharapkan gas metana yang akan diproduksi bisa lebih meningkat sampai dengan $50-70 \%$.

Tabel 1 : Hasil Komposisi Sampah Denpasar, Badung, Gianyar dan Tabanan. ${ }^{8)}$

\begin{tabular}{|l|l|l|l|}
\hline $\begin{array}{c}\text { ITEM } \\
\text { Sampah }\end{array}$ & $\begin{array}{c}\text { SEL 1 } \\
\text { Dry }\end{array}$ & $\begin{array}{c}\text { SEL 2 } \\
\text { Wet }\end{array}$ & $\begin{array}{c}\text { SAMPAH } \\
\text { BARU }\end{array}$ \\
\hline Organik & $67 \%$ & $65 \%$ & $66 \%$ \\
\hline An-Organik & $33 \%$ & $35 \%$ & $34 \%$ \\
\hline $\begin{array}{l}\text { BJ Sampah } \\
\text { Organik }\end{array}$ & 0.25 & 0,27 & 0,18 \\
\hline $\begin{array}{l}\text { BJ Sampah } \\
\text { An-Organik }\end{array}$ & 0.21 & 0,16 & 0,20 \\
\hline $\begin{array}{c}\text { BJ Sampah } \\
\text { Campuran }\end{array}$ & 0.26 & 0,25 & 0,19 \\
\hline
\end{tabular}

\subsection{Sistem Pengolahan Sampah}

Pengolahan sampah TPA Suwung mempunyai luas sekitar 26 ha, namun yang dimanfaatkan untuk kegiatan pemanfaatan sampah menjadi listrik hanya 10 ha. Potensi sampah wilayah Sarbagita sekitar 800 ton per hari dan diprediksi dapat menghasilkan listrik 9,6 megawatt (Bernt Harald Bakken, 2007). Namun saat ini pemasokkan sampah baru mencapai 350 - 500 ton per hari. 
Sampah yang selama ini ditumpuk dalam system open dumping dilakukan penutupan dan pemasangan jaringan pipa dan sumur untuk menangkap gas yang terbentuk. Gas dari Landfill dan system sel dihisap dengan pompa vacum, kemudian dilakukan pretreatment untuk menghilangkan kandungan air dan partikulat, kemudian dijadikan bahan bakar mesin. Saat percobaan dilakukan baru bisa dihidupkan satu mesin dengan produksi listrik 470 kilowatt. Seluruh terdapat 4 mesin dengan kapasitas masing-masing 1 megawat.

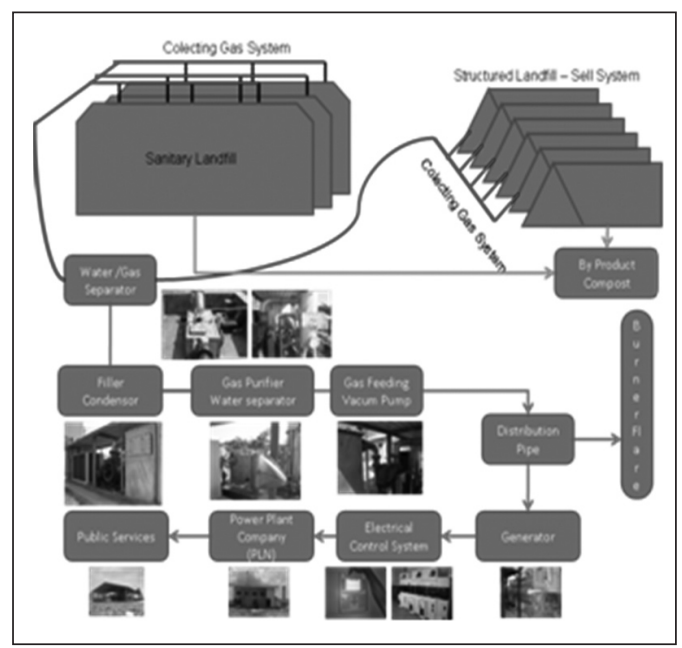

Gambar 5: Integrated System of Solid Waste to Energy (IPST) Sarbagita TPA Suwung. ${ }^{5}$

\subsection{Sistem Sel Sampah}

TPA sampah Sistem Sel mempunyai kapasitas $12.000 \mathrm{~m}^{3}$ sampah dan diprediksi dapat memproduksi listrik 364 kW. Setiap Sel Sampah mempunyai dimensi lebar : 20 meter. Panjang : 28 meter, dan Tinggi : 12 meter. Dinding terbuat dari konstruksi beton bertulang, dan bagian atas ditutup dengan menggunakan terpal plastik. Dibagian bawah sel terdapat saluran lindi yang dikumpulkan kearah depan dengan kemiringan 5\% dimasukkan kedalam pipa pengumpul. Sistem dilengkapi dengan pipa untuk melakukan sirkulasi air (bisa air lindi atau air yang sudah mengalami perlakuan khusus).

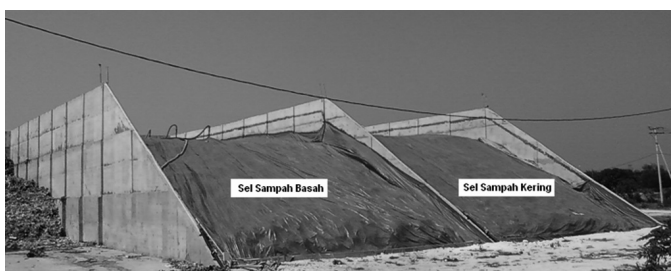

(a)

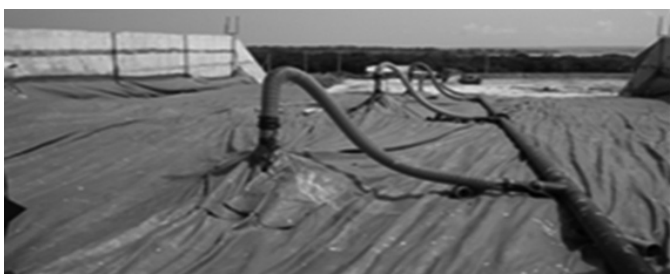

(b)

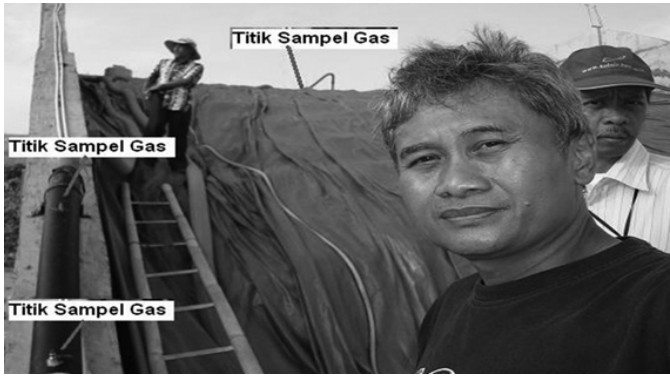

(c)

Gambar 6 : (a). Sel Sampah Basah (kiri) dan Kering (kanan). (b). Sumur pengumpul dan pipa kolektor gas terletak di atas sel sampah, (c). Lokasi titik sampel gas.

Sumur pengumpul gas dengan diameter 6" ditanam setiap jarak 5 meter dibagian tengah sampai pada kedalaman 12 meter. Gas dari setiap sumur dikumpulkan dengan pipa fleksible dan dialirkan kebagian depan sel dan siap dihisap gasnya. Penghisapan di pusat pompa dilakukan sampai pada tekanan $-50 \mathrm{mb}$, namun dikontrol dengan gas oksigen yang terhisap tidak boleh lebih dari $6 \%$.

Hasil observasi lapangan menunjukkan adanya penurunan produksi gas metana dalam beberapa bulan terakhir. Penurunan diduga karena adanya perubahan musim dari hujan ke kemarau, atau akibat rusaknya 
lapisan penutup, atau terjadinya gangguan proses dekomposisi sampah dalam sel.

Tabel 2 : Spesifikasi Tpa Sistem Sel, Suwung, Denpasar, Bali.

\begin{tabular}{|lll|}
\hline \multicolumn{2}{|l|}{ SPESIFIKASI FISIK } \\
\hline Lebar & $:$ & 20 meter \\
Panjang & $:$ & 28 meter \\
Tinggi & $:$ & 12 meter \\
Volume & $:$ & $12000 \mathrm{~m}^{3}$ sampah $/$ Sel \\
Power Desain & $:$ & $364 \mathrm{kw} / \mathrm{sel}$ \\
Power Eksisting & $:$ & $200 \mathrm{kw} / \mathrm{sel}$ \\
Penutup & $:$ & Plastik Terpal \\
Sistem & $:$ & Anaerobik \\
Pipa Fleksible & $:$ & 6 " PVC \\
Klep Penutup & $:$ & 6 " Besi \\
Pipa Sentral & $:$ & 8 " Besi \\
Pompa Hisap & $:$ & maks $70 \mathrm{mlbar}$ \\
Oksigen & $:$ & $<6 \%$ \\
Metana & $:$ & $28-50 \%$ \\
\hline
\end{tabular}

\section{HASIL}

\subsection{Sistem Sanitasi Lingkungan}

Sistem sanitasi lingkungan terjaga dengan baik, bau sampah tidak terlalu menyengat karena Sel Sampah tertutup terpal, air lindi terkendali, kebocoran lindi dapat terjadi akibat penyelesaian struktur bangunan yang kurang sempurna, bukan karena kegagalan sistem. Dengan demikian sistem sel dapat lebih menjamin sistem sanitasi lingkungan sekitarnya

\subsection{Pemadatan Sampah}

Hasil pengamatan visual fisik di lapangan, nampak bahwa kedua sistem sel, baik Dry Cell maupun Wet Cell keduanya mengalami proses pemadatan (ambles). Selama dua bulan terakhir penurunan mencapai $200 \mathrm{~cm}$. Sel 2 (Wet Cell) lebih cepat mengalami pemadatan dibanding Sel 1 (Dry Cell), dengan selisih rata-rata sekitar $50 \mathrm{~cm}$ dalam waktu dua bulan. Adanya amblesan ini menjadi pertimbangan dalam penentuan konstruksi lapisan penutup dimasa datang, sehingga tidak terjadi kerusakan (robek) terpal pada bagian pinggir (pengikat).

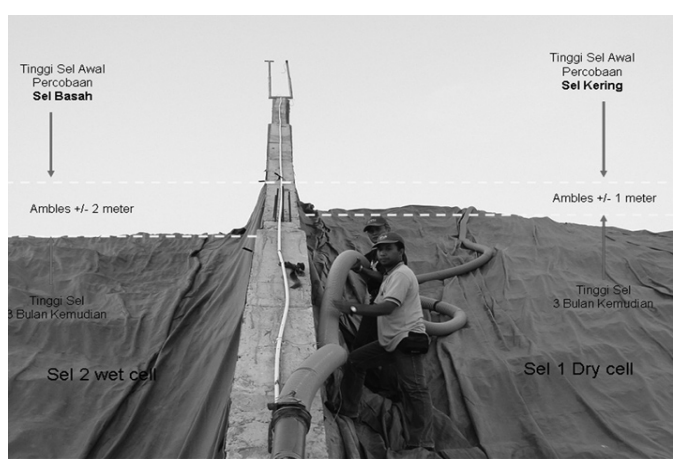

Gambar: 7 Perbedaan amblesan antara sel sampah basah (kiri) dan kering (kanan).

\subsection{Peran Lapisan Penutup}

Lapisan penutup mempunyai peran besar, karena seluruh gas yang diproduksi dan muncul dipermukaan sampah ditangkap pada lapisan ini. Jika bocor akan banyak gas yang terbuang. Lapisan penutup juga melindungi sel sampah dari proses penguapan yang berlebihan dan mencegah kontak sampah dengan udara secara langsung, karena pada dasarnya proses yang sedang berlangsung adalah anaerobik. Kebocoran lapisan atau pipa gas dapat diindikasikan dengan meningkatnya kadar oksigen dalam gas dan menurunnya produksi gas metana.

\subsection{Penyiraman Air}

Proses penyiraman dengan air dimaksudkan agar sampah tidak terlampau kering, sehingga proses pembusukan dapat berjalan dengan baik dan produksi gas metana akan meningkat. Penyiraman Sel 2 (Wet Cell) pada periode Juli sd Agustus dilakukan dengan pompa submercible 11,5 kw (air yang digunakan air lindi), namun pada bulan Oktober sd November pompa diganti dengan yang lebih kecil, yakni kekuatan $1,5 \mathrm{~kW}$ yang berjumlah dua buah 
dipasang seri dan air penyiraman digunakan air hasil olahan dari pengolahan limbah kota Denpasar, diangkut dengan menggunakan truk tangki, kemudian dituangkan dalam tangki penampung.

Target penyiraman adalah membuat kondisi sampah menjadi lembab, sekitar 60 $65 \%$, sedangkan pada Sel 1 tidak dilakukan penyiraman (kelembaban sekitar 50 $55 \%$ ). Penyiraman membawa konsekuensi biaya yang harus diperhitungkan dengan penambahan benefit dari peningkatan produksi gas metananya.

Kondisi yang diamati selama dan setelah proses penyiraman dilakukan adalah terjadi fenomena turunnya produksi gas metana sesaat, yaitu dari $20-22 \%$ menjadi $10-12 \%$ dan naiknya gas oksigen dari $6-8 \%$ menjadi 8-12\%.

Perubahan ini dapat terjadi karena air yang dimasukkan membawa oksigen, sehingga mengganggu kesetimbangan gas-gas yang ada. Namun sehari kemudian Oksigen turun kembali dan konsentrasi gas metana meningkat akibat penyiraman (Gambar 8).

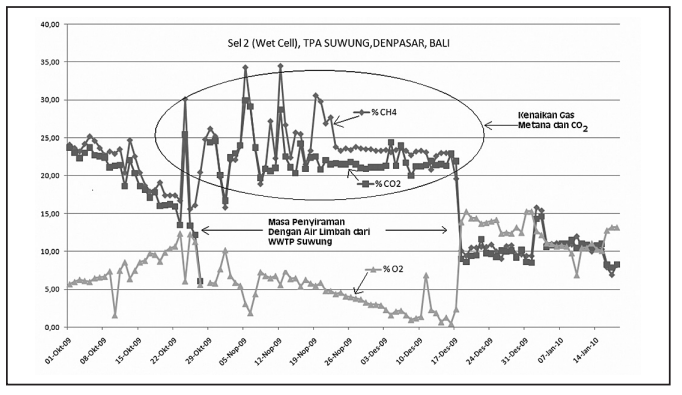

Gambar: 8. Pengaruh penyiraman terhadap Kenaik-an konsentrasi gas metana dan $\mathrm{CO}_{2}$ dalam Sel 2 (Wet Cell).

\subsection{Gas Metana}

Jika dibandingkan produktifitas gas metana pada TPA Sistem Sel 1 Kering (Dry Cell) dan Sistem Sel 2 Basah (Wet Cell), selama pengamatan hampir lima bulan (Juli s/d November) menunjukkan kinerja yang tidak jauh berbeda (Gambar 8 dan Gambar 9).

Kandungan Gas Metana yang dihasilkan besarannya berkisar 15 sd 52\%, Sistem Dry Cell cenderung lebih stabil dan tinggi sedikit dibandingkan Sistem Wet Cell. Percobaan dilakukan selama musim peralihan hujankemarau

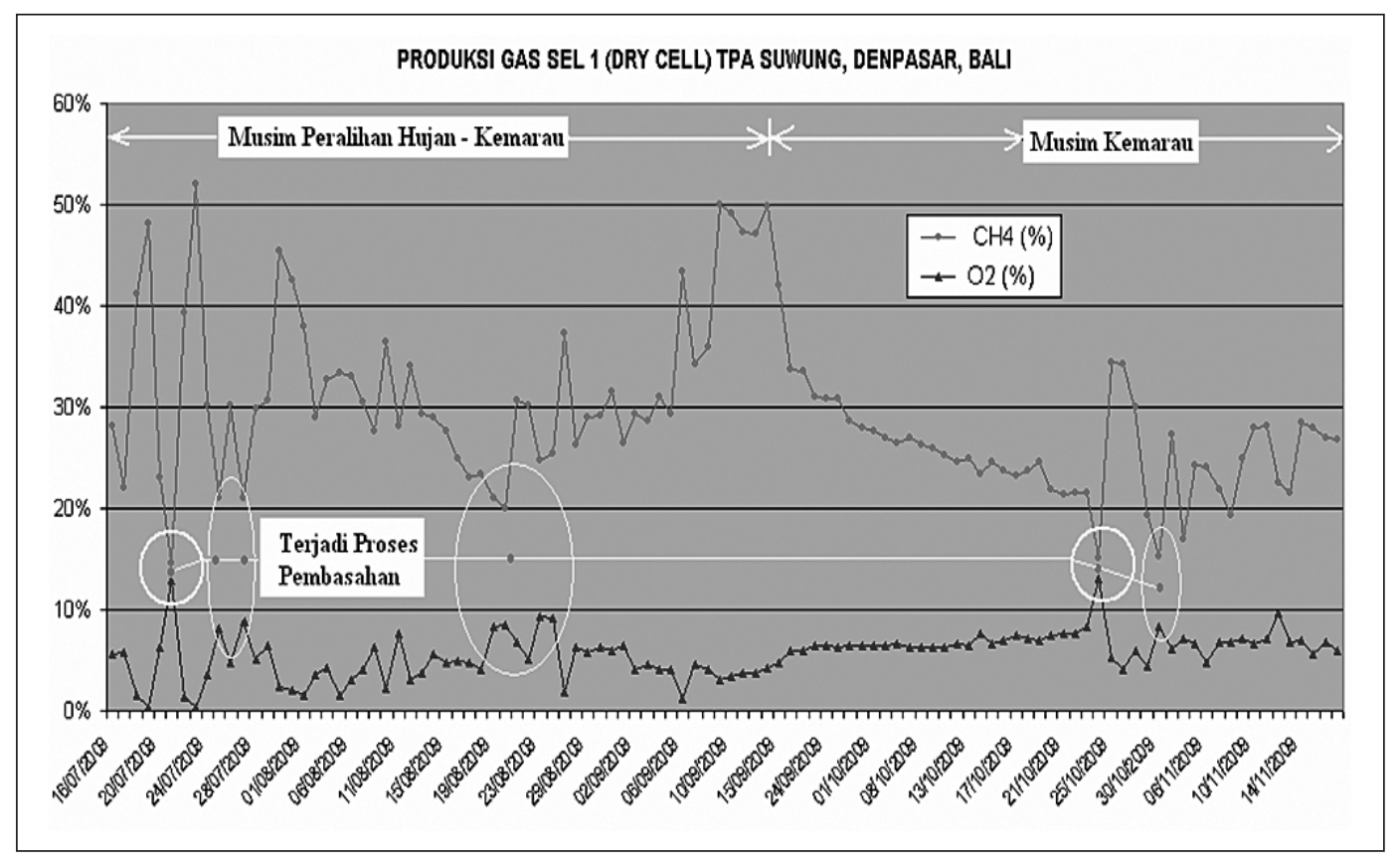


Sampai dengan musim kemarau. Untuk keperluan pembangkit listrik diperlukan kandungan gas $\mathrm{CH}_{4}$ minimal 28\% (sesuai dengan spesifikasi mesin pembangkit yang digunakan), kandungan $\mathrm{O}_{2}$ tidak boleh melebihi $6 \%$. akan mengganggu proses pembentukan gas metananya, disamping pengaliran air itu sendiri akan membawa oksigen kedalam sistem anoksik. Gas metana dalam sampah jika ingin dimanfaatkan diperlukan upaya pemanenan, dengan cara memasang sumur.

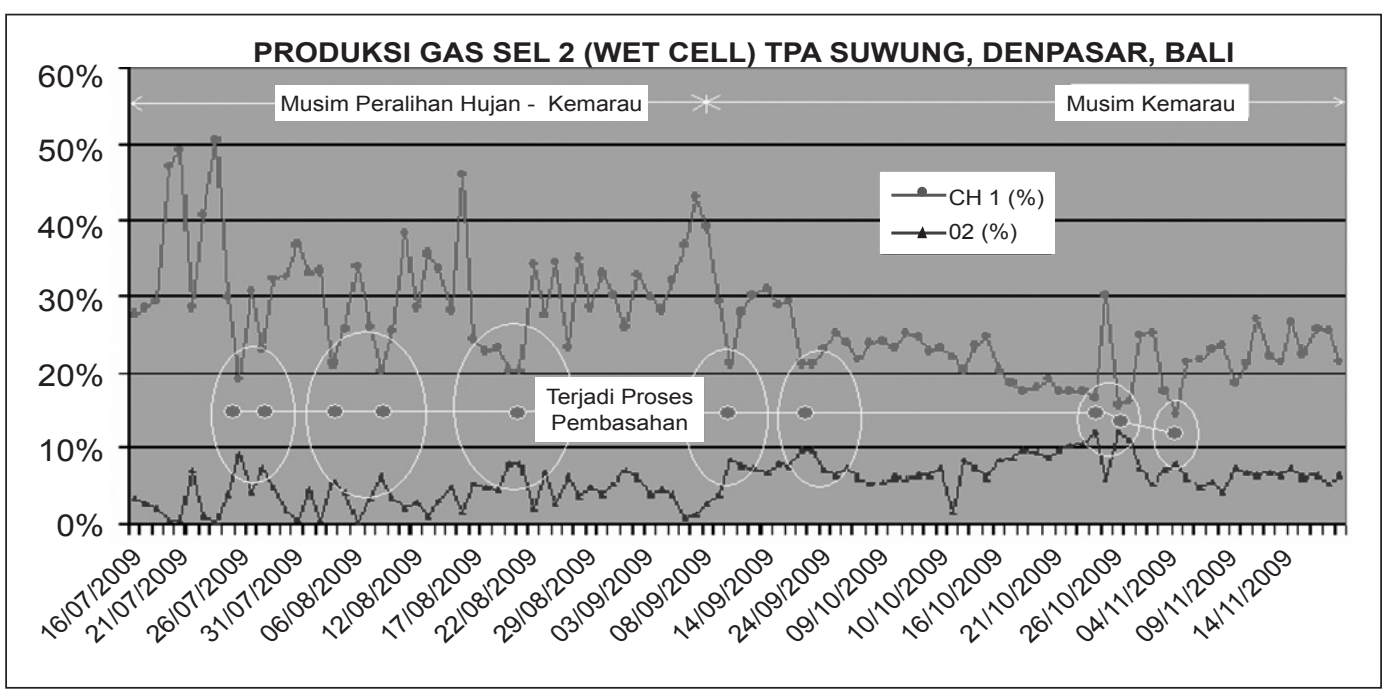

Gambar 10 : Produksi Gas Metana dan Oksigen Sel 2 (Wet Cell) Bulan Juli sd November 2009

Pada Sel 1 Dry Cell proses pembasahan dapat terjadi akibat hujan yang merembes melalui atap, terutama pada bagian-bagian yang tidak terawat (terpal robek), akibatnya terjadi peningkatan oksigen dan menurunnya gas metana di beberapa titik pengamatan.

Berbeda dengan Sel 1, maka sel 2 Wet Cell, sistemnya dilengkapi dengan pompa penyiraman untuk pembasahan sampah. Pada bulan Juli sd Agustus proses penyiraman cukup intensif dan pompa yang digunakan cukup besar (11,5 kw). Pada Gambar 8 terlihat bahwa produksi gas metana sering terganggu (turun) akibat periode penyiraman yang tidak teratur, sehingga menggangu proses yang ada.

Oleh karena itu ada beberapa hal yang perlu dipelajari lebih lanjut. Air yang digunakan untuk menyiram pada periode tersebut adalah air lindi (leachate) yang pH-nya cukup rendah, sehingga jika dikembalikan pada suatu sistem yang sedang berada pada proses metanogenesis ( $\mathrm{pH}$-nya berkisar 6 - 8), maka
Pemasangan sumur harus memperhatikan radius pengumpulan, yang disesuaikan dengan besar dan tingginya tumpukan sampah.

Hal lain yang perlu dipertim-bangkan adalah umur sampah. Pada saat pengisian Sel Sampah, karena keterbatasan jumlah sampah dan armada angkutan yang ada, maka tidak memungkinkan kedua Sel Sampah penuh secara bersama-sama. Pada saat percobaan Sel 1 Dry Cell lebih dahulu diisi dibandingkan Sel 2 Wet Cell.

\subsection{Oksigen}

Selama percobaan diusahakan agar kandungan oksigen kurang dari $6 \%$. Kandungan oksigen yang tinggi menunjukkan adanya kebocoran pada bagian penutupan atau proses penghisapan oleh pompa vakum terlalu kuat. Terpal penutup bisa rusak (robek) terjadi akibat usia, atau akibat tertiup angin kencang atau rusak karena tidak tahan terhadap sinar matahari (rapuh). 
Pada Sel 2 (Wet Cell), proses pembasahan dapat meningkatkan kandungan $\mathrm{O}_{2}$ dan menurunkan kandungan gas $\mathrm{CH}_{4}$, namun secara perlahan naik kembali dalam waktu sekitar satu minggu.

Jika kandungan oksigen terlampau banyak, sebagian gas $\mathrm{CH}_{4}$ akan berubah menjadi $\mathrm{CO}_{2}$. Penghisapan oleh pompa vacum yang terlalu kuat akan meningkatkan kandungan $\mathrm{O}_{2}$, oleh karena itu diperlukan pengaturan manual untuk menentukan besarnya bukaan tutupan klep pompa.

\subsection{Karbon Monoksida}

Kandungan karbon monoksida (CO) dalam sampah rendah (<10 ppm) pada sampah muda (<3 bulan), meningkat sampai 40 sd 100 ppm pada usia sedang (3 - 6 bulan), dan tinggi pada sampah yang tua ( dapat mencapai 250 ppm). Pada landfill yang siap dipanen gasnya kandungan $\mathrm{CO}$ cenderung tinggi.

\subsection{Hidrogen Sulfida}

Dalam penelitian ini kandungan gas sulfida tidak terlampau banyak dan cenderung rendah, berkisar 0 sd 4 ppm. Kondisi terkait dengan komposisi sampah yang tidak banyak mengandung protein.

\subsection{Program transfer data}

Untuk membaca satu serial data yang panjang dan akurat, diperlukan kemahiran dalam membaca data logger yang ada dalam peralatan Ga2000 plus. Dalam penelitian ini berhasil dibangun miniprogram untuk pembacaan data Ga2000 plus dan penyusunan database untuk analisis performance TPAyang sangat diperlukan dalam penelitian gas landfill

\section{KESIMPULAN}

1. Sistem sel ini dapat dipakai sebagai simulator operasional dan kinerja TPA RSL.
2. Teknologi Pengolahan Sampah Kota dengan Sistem Sel basah dan kering terbukti tidak menimbulkan bau yang menyengat dan sanitasi ling-kungannya dapat dikendalikan dengan baik. Sesuai untuk pengolahan sampah organik di kawasan pesisir pantai dan dataran rendah.

3. Proses pembentukan gas $\mathrm{CH}_{4}$ pada sistem sel (1 dan 2), dapat mencapai > $35 \%$, cukup untuk digunakan sebagai sumber energi. Jika kondisi sampah terpilah dan sistem tertutup baik, maka gas $\mathrm{CH}_{4}$ dapat mencapai $50 \%$.

4. Penurunan tinggi sampah mencapai 1,5 sd 2 meter dalam 3 bulan, sel basah lebih cepat mengalami penurunan. Proses penurunan sampah lebih cepat pada Sel 2 Wet Cell dan resiko robeknya lapisan penutup menjadi tinggi.

5. Proses pembasahan akan meningkatkan produksi gas $\mathrm{CH}_{4}$, namun perlu pengaturan jangka penyiraman agar tidak menganggu proses pembentu-kan gas $\mathrm{CH}_{4}$ yang sedang berlangsung.

6. Proses pembasahan membutuh-kan biaya tambahan untuk pengangkutan air dan tenaga listrik untuk pompa penyiraman. Daya listrik pompa air pada sistem sel eksisting dapat diturunkan dari $11,5 \mathrm{~kW}$ menjadi $1,5 \mathrm{~kW}$ tanpa mempengaruhi produk-tifitas gas metana.

7. Proses metabolisme sampah dapat dilihat dari kandungan CO-nya, pada sampah muda kandungan CO-nya berkisar 0 sd 10 ppm, sampah sedang 40 sd 60 ppm, dan sampah yang sudah tua berkisar 100 sd 350 ppm.

\section{SARAN}

1. Perlu diupayakan penutup plastik yang tahan terhadap radiasi sinar matahari.

2. Perlu dilakukan pemilahan sampah sebelum sampah dimasukkan kedalam sistem sel, agar kandungan organiknya bisa ditingkatkan hingga $80 \%$ dan 
produksi gas metananya menjadi lebih optimal.

3. Penurunan tumpukan sampah berkisar 0,75 sd 1,00 per bulan menyebabkan tutup sel rusak atau robek, sehingga perlu dibuat konstruksi tutup sel yang dapat mengikuti penurunan tumpukan sampah.

4. Agar gas yang terkumpul dapat efektif tertampung dalam sumur, maka perlu dibuat jaringan pengumpul gas yang radier (terdiri paling tidak empat pipa fleksible yang perforated - pipa dari tepi menuju kepusat pipa kolektor).

5. Posisi titik pengukuran gas sebaiknya dibagian atas agar lebih mewakili potensi gas yang sebenarnya. Sel perlu diberi waktu yang cukup untuk memproduksi gas sebelum dipanen, pemanenan gas perlu bergantian antar sel, waktu retensi paling tidak 5 sd 7 hari.

6. Pompa sirkulasi air untuk proses pembasahan tidak perlu terlalu besar hingga $11,5 \mathrm{kw}$, tetapi cukup menggunakan 2 buah pompa $0,75 \mathrm{kw}$. Proses pembasahan sampah tidak perlu terlalu jenuh.

7. Pembuatan dinding beton sel masih mahal, oleh karena itu disainnya perlu modifikasi agar volume dindingnya dapat dikurangi.

8. Pemasangan sumur gas pada sistem sel, perlu diubah karena posisinya menghalangi excavator pada saat pemanenan kompos.

9. Sistem transfer data dari GA2000 plus dan software analisis database sangat diperlukan untuk membantu kecepatan analisis data gas TPA. Dalam penelitian ini juga berhasil dirakit Analog Landfill Gas Measurement Instrument (ALGMI).yang sangat membantu dalam pengukuran dengan menggunakan GA2000 plus.

\section{DAFTAR PUSTAKA}

1. --------, 1987, Study on Solid Wase Management System Improvement Project in The City of Jakarta in Indonesia, JICA.
2. -------, 2005, Solid Waste Management for Jakarta: Master Plan Review and Program Development, Dinas Kebersihan Propinsi DKI Jakarta.

3. Anonim, 1990. Studi Daur Ulang Sampah Domestik dari Sumber-nya (Studi Kasus Jakarta Timur. Laporan Akhir. Kelompok Sanitasi Lingkungan BPPT dengan P4L DKI Jakarta.

4. Anonim, 1996. Solid Waste Recycling Plant in Surabaya Indonesia.

5. Arie Herlambang, Henky Sutanto, Heru Dwi Wahyono, Petrus Nugro Rahardjo, Nusa Idaman Said, Suprapto, Joko Heru Martono, Asep Waluyo, Taty Hernaningsih, Satmoko Yudho dan Kusno Wibowo, 2009, Teknologi Pengolahan Sampah Kota Intermediate Treatment (Cell System), DIKTI- BPPT.

6. Morton A. Barlaz, 1998, Carbon storage during biodegradation od municipal solid waste component in laboratory scale landfill, Global Biogeochemical Cycles, Vol. 12, No. 2, Pages 373 -380.

7. Paul.N.C, dan Angelo.C.M, 1976, Energy From Solid Waste, Marcel Dekker, Inc, New York.

8. Suprapto dan Asep Waluyo, 2009, Karakterisasi Sampah Wilayah Denpasar, Badung, Gianyar, dan Tabanan, Bali, Laporan Survei, BPPT.

9. Tchobanoglous. G, Thiesen.H, Eliseen. R, 1977, Solid Wastes : Engineering Principles and Management Issues, McGraw-Hill, Ltd, Kogaskusha.

\section{UCAPAN TERIMAKASIH KEPADA :}

1. Departement Pendidikan dan Kebudayaan, yang telah membantu dalam pendanaan penelitian ini.

2. PT. Navigat Organics Energy Indonesia Denpasar dan BKSP Sarbagita Provinsi Bali dan Satker DPU Provinsi Bali yang telah memberikan kesempatan untuik melakukan penelitian ini. 